\title{
The Methodology of Architectonic Truth-Finding in Grass's The Tin Drum (Die Blechtrommel)
}

\author{
Stephan Schaffrath \\ Slippery Rock University and Indiana University of Pennsylvania
}

Follow this and additional works at: https://docs.lib.purdue.edu/clcweb

Dedicated to the dissemination of scholarly and professional information, Purdue University Press selects, develops, and distributes quality resources in several key subject areas for which its parent university is famous, including business, technology, health, veterinary medicine, and other selected disciplines in the humanities and sciences.

CLCWeb: Comparative Literature and Culture, the peer-reviewed, full-text, and open-access learned journal in the humanities and social sciences, publishes new scholarship following tenets of the discipline of comparative literature and the field of cultural studies designated as "comparative cultural studies." Publications in the journal are indexed in the Annual Bibliography of English Language and Literature (Chadwyck-Healey), the Arts and Humanities Citation Index (Thomson Reuters ISI), the Humanities Index (Wilson), Humanities International Complete (EBSCO), the International Bibliography of the Modern Language Association of America, and Scopus (Elsevier). The journal is affiliated with the Purdue University Press monograph series of Books in Comparative Cultural Studies. Contact: <clcweb@purdue.edu>

\section{Recommended Citation}

Schaffrath, Stephan. "The Methodology of Architectonic Truth-Finding in Grass's The Tin Drum (Die Blechtrommel)." CLCWeb: Comparative Literature and Culture 9.4 (2007): <https://doi.org/10.7771/1481-4374.1299>

This text has been double-blind peer reviewed by $2+1$ experts in the field.

The above text, published by Purdue University Press (CPurdue University, has been downloaded 2893 times as of $11 /$ $07 / 19$.

This document has been made available through Purdue e-Pubs, a service of the Purdue University Libraries. Please contact epubs@purdue.edu for additional information.

This is an Open Access journal. This means that it uses a funding model that does not charge readers or their institutions for access. Readers may freely read, download, copy, distribute, print, search, or link to the full texts of articles. This journal is covered under the CC BY-NC-ND license. 


\section{PURDUE}

UNIVERSITY PRESS <http://www.thepress.purdue.edu>

\section{CLCWeb: Comparative Literature and Culture}

ISSN 1481-4374 <http://docs.lib.purdue.edu/clcweb> Purdue University Press (C)Purdue University

CLCWeb: Comparative Literature and Culture, the peer-reviewed, full-text, and open-access learned journal in the humanities and social sciences, publishes new scholarship following tenets of the discipline of comparative literature and the field of cultural studies designated as "comparative cultural studies." In addition to the publication of articles, the journal publishes review articles of scholarly books and publishes research material in its Library Series. Publications in the journal are indexed in the Annual Bibliography of English Language and Literature (Chadwyck-Healey), the Arts and Humanities Citation Index (Thomson Reuters ISI), the Humanities Index (Wilson), Humanities International Complete (EBSCO), the International Bibliography of the Modern Language Association of America, and Scopus (Elsevier). The journal is affiliated with the Purdue University Press monograph series of Books in Comparative Cultural Studies. Contact: <clcweb@purdue.edu>

\section{Volume 9 Issue 4 (December 2007) Article 2 Stephan Schaffrath, "The Methodology of Architectonic Truth-Finding in Grass's The Tin Drum (Die Blechtrommel)" \\ <http://docs.lib.purdue.edu/clcweb/vol9/iss4/2>}

\section{Contents of CLCWeb: Comparative Literature and Culture 9.4 (2007)}

<http://docs.lib.purdue.edu/clcweb/vol9/iss4/>

Abstract: Stephan Schaffrath, in his paper "The Methodology of Architectonic Truth-Finding in Grass's The Tin Drum (Die Blechtrommel)," discusses how Günter Grass's The Tin Drum (Die Blechtrommel) negotiates the treacherous terrains that lie between positivism and nihilistic relativism by means of a truth-finding methodology. Schaffrath proposes that truth-finding methodology applies approximative, and therefore architectonic, approaches to conventional concepts of narration and history. Grass's novel breaks down and reassembles playfully the conventions of narration and history, not to negate or devalue them, but to reappraise them by means of an approximative truth-finding methodology, an approach that corresponds to Mikhail Bakhtin's concept of the architectonic. An architectonic historical narrative is achieved here by re-creating consciously recent German history instead of a conventional historical narration that claims a certain degree of objectivity. Grass shows us that the genre of the novel can indeed convey history in a fictitious format (an otherwise standard recognition in the humanities today), yet be a useful and insightful medium to those who wish to learn about history in the sense of a factual genre. Grass achieves this by educating his readers about the fine line between fact and fiction as he interweaves a most intricate epistemological commentary into the narrative of his narrator. 
Stephan Schaffrath,

"The Methodology of Architectonic Truth-Finding in Grass's The Tin Drum (Die Blechtrommel)" page 2 of 12

CLCWeb: Comparative Literature and Culture 9.4 (2007): <http://docs.lib.purdue.edu/clcweb/vol9/iss4/2>

\section{Stephan SCHAFFRATH}

\section{The Methodology of Architectonic Truth-Finding in Grass's The Tin Drum (Die Blechtrommel)}

In his first and internationally best known novel -- for which he received the 1999 Nobel Prize in Literature -- The Tin Drum (Die Blechtrommel), Günter Grass negotiates the treacherous terrains that lie between positivism and nihilistic relativism by means of a truth-finding methodology that applies approximative, and therefore architectonic, approaches to conventional concepts of narration and history. Grass plays with these concepts of narration and history, rearranges them, and compares and contrasts them. Not unlike the archetypal trickster figures of folklore (see Jung; Arnds) and world literatures, Grass breaks down and playfully reassembles the conventions of narration and history, not to negate or devalue them, but to reappraise them by means of an approximative truth-finding methodology, a novelist's approach to exploring novelistic "truths," one that corresponds to Mikhail Bakhtin's concept of the architectonic (see also Neuhaus; Arnds). Grass's novel accomplishes an architectonic historical narrative by recreating recent German history by means of an approximative perspective on the concept of truth, in the sense of "finding truth" and "finding something to be true," especially in context with the more specific concepts of narration and history. In the novel Grass employs an approach that is neither fictional nor historical. However, his approach is not simply a combination or mélange of fiction and history. Grass deals with what was then (in the 1950s) recent German history in a manner that is best described as an approximative approach to truth-finding in the vein of Mikhail Bakhtin's theory of the architectonic (Bakhtin uses the term "architectonic" relatively late in his book length essay Toward a Philosophy of the Act where he discusses the moral implications and applications of his philosophy). Through his narrator Oskar, Grass fashions a conveyer of oral history who does not simply integrate his personal experiences in his relaying of German history before, during, and after the Second World War. Oskar becomes the self-proclaimed epic protagonist of history. The so-called objective, probably factual stuff of history books gets meshed together with the more subjective, sometimes suspicious and questionable material of legends, grand illusions (as well as allusions, of course), magic realism, admitted and often shameless subjectivity, and narrator unreliability; things which can easily be rejected as flawed and perhaps even erroneous, despite the fact that they are such prolific, effective, and often essential elements of human storytelling. This meshing together of elements which make up a work that constitutes both non-fiction as well as fiction is the basis for Grass' architectonic approach that richly illustrates Oscar's horrid adventure, especially amid the throws of National Socialist history, while it also serves as a commentary for the irretrievability of those things that are frozen in the past. The Tin Drum is a work that not only comments on the empirical nature that calls into question the veracity of all historical accounts, regardless of their intended objectivity or their allowance for subjectivity. It also serves both author and reader as a tool for confronting and evaluating historical truths or methods of "finding of truths." Grass's novel may thus be seen as a truth-finding tool and it does so by means which are congruous to Bakhtin's architectonics.

One of Bakhtin's lesser known, architectonics is one of his earliest, philosophical and literary coinages. It forms the foundations for Bakhtin's later and better known literary terms of heteroglossia, dialogic, and the carnivalesque (see, eg., his The Dialogic Imagination). It is essentially a conceptualization of spatial and temporal empiricism. Architectonics is a useful model in the world of literary criticism not just in combination with Bakthin's better known concepts, all of which rest on its shoulders. By itself, architectonics provides conceptual terminology that helps identify and define a literary work's philosophical approach, in particular its truth-finding methodology -- the way authors manage the concept of truth within their literary works. Bakhtin defines our world in terms of experiences, picking up roughly where Immanuel Kant's phenomenology left off. Bakhtin leans heavily on German philosophers of the enlightenment, in particular Immanuel Kant, who focused on the experience and percep- 
Stephan Schaffrath,

"The Methodology of Architectonic Truth-Finding in Grass's The Tin Drum (Die Blechtrommel)" page 3 of 12

CLCWeb: Comparative Literature and Culture 9.4 (2007): <http://docs.lib.purdue.edu/clcweb/vol9/iss4/2>

tion of the world, as that is the way we "know" things. The German terms Sein and Dasein roughly translate as "conscious existence" and "existing ( $\mathrm{t}$ )here" and are adopted and adapted by the term "Being" with a capital B (see Schulte 473; Kant was from the then German Königsberg, now the main city of the Russian enclave on the southeastern Baltic coast known as Kaliningrad, not far from Danzig/Gdańsk, and similarly connected to German history). For Bakhtin, everything there is can best be described as acts or deeds, terms that are to be understood in the sense of experienced and participatory events. He explains: "I, too, participate in Being in a once-occurrent and never-repeatable manner: I occupy a place that cannot be taken by anyone else and is impenetrable for anyone else. In the given once-occurrent point where I am now located, no one else has ever been located in the onceoccurrent time and once-occurrent space of once-occurrent Being. And it is around this once-occurrent point that all once-occurrent Being is arranged in a once-occurrent and never-repeatable manner. That which can be done by me can never be done by anyone else. The uniqueness or singularity of present-on-hand Being is compellently obligatory" (Toward a Philosophy of the Act 40). Since, in the absence of time-traveling devices, no one can reproduce an event that has already occurred, Bakhtin defines all experiences as acts which occur once only within space-time-continuum and are therefore irretrievably frozen in their chronotopal dimension. One may attempt acts that are aimed at reproducing former acts, but it is ultimately impossible to do the same thing twice. Any attempt to reproduce an act constitutes a new act. This consciousness of the once-occurrent, never-repeatable nature of all experiences becomes apparent in Oskar's tale, although Grass never alludes or refers to Bakhtin's philosophy. Nevertheless, both created "architectonic" commentary, Grass through fiction and Bakhtin in his scholarship.

I should like to mention here that my analysis of The Tin Drum's narrative method is similar to Eung-Jun Kim's in his Literatur als Historie (Literature as Historical Narrative). He describes Grass's narrative approach to history as one that derives directly from the reader's experience and is thus not only cultural and historical but also has a societal component. Kim calls Oskar's narration method "realistic," more so in style than in substance. He focuses on how Grass's/Oskar's method of narration opens new societal interpretations. Kim comes closest to my own Bakhtinian interpretation when he shows Oskar as a character who resists readers' identification, causing readers to look from the outside into the story (64-65). He also uses the notion "verfremdenen Effekt der Darstellung" ("alienating effect of representation"), which is related, although distinct from an architectonic interpretation (74; another scholar who makes several interesting observations about Grass's narrative methods is Jochen W. Rohlfs. In his article "Chaos or Order? Günter Grass's Kopfgeburten," Rohlfs mentions the Grassian term Vergegenkunft: the term is a collage of the three German words/concepts, Vergangenheit, Gegenwart, and Zukunft (past, present, and future). The Tin Drum's Bakhtinesque truth-finding methodology is most apparent in its narration and history. Oskar is simultaneously narrator and conveyor of an alternative sort of history. The subjects of narration and history are dealt with in a way that show Grass's sensitivity for lived or participated history and its conveyance through a consciously narrated and therefore re-created act of story/history-telling. Grass and Bakhtin share this sensitivity, one as a novelist, the other as a literary theorist: Bakhtin discusses it and Grass applies it. Their work betrays a similar love for what may be phrased either an architectonic or an approximative truth-finding methodology (on this, see in detail in Schaffrath). In the following, I discuss narration and history as the two primary tools Grass uses to create such an approach to finding truth. Oskar's narration is consciously and overtly set apart from the actual events that are narrated. Grass treats Oskar's narration as an act that is distinct from the events that are narrated. While at first such an observation may suggest a diminished role for the narration act, Bakhtin's philosophy can be helpful in understanding that no one act can be accurately measured or compared to another act in terms of its worth or value. Narration acts are genuine, original, and unique acts in and of themselves. They may be seen as a means of conveyance of information about the act or deed that they narrate, but they are by no means lesser in value or significance. They are unique and ultimately immeasurable, and 
Stephan Schaffrath,

"The Methodology of Architectonic Truth-Finding in Grass's The Tin Drum (Die Blechtrommel)" page 4 of 12

CLCWeb: Comparative Literature and Culture 9.4 (2007): <http://docs.lib.purdue.edu/clcweb/vol9/iss4/2>

they are therefore not to be measured side-by-side with the act that they describe or narrate. These narration acts are neither valuable nor appreciable, neither in a positive nor a negative sense. Bakhtin's philosophy can help readers understand that Oskar's act of narration is an act in and of itself. Although intended to reflect upon past events, it has a meaning of its own, separate from the events that it reflects upon. Grass makes a clear distinction between narration act and the act that the narration act reflects upon (the contents of narration). This parallels the architectonic philosophy of Bakhtin, who posits that "once-occurrent uniqueness or singularity cannot be thought of, it can only be participatively experienced or lived through" (Toward a Philosophy of the Act 13). The fantastic and often unbelievable nature of Oskar's narration can thus be seen in a particular light, one that shows that a critical and philosophical commentary pervades Grass's novel. Oskar is not simply the conveyor of errors or embellishments of an egocentric storyteller to his audience. These elements are part of another act, part of a new (and consciously so) creation, rather than a re-creation of the Oskar of the past.

As the narrating Oskar of the 1950s is lying on his bed in his room in the sanatorium, he experiences memories -- which are acts in themselves -- and uses these to shape narration acts, which are necessarily unique and therefore new, never-repeatable creations. The act of recording these memory acts on paper simply creates the illusion of repeatability. As Grass, through his narrator Oskar, comments on the distinction between narration act and the acts that the narration describes, readers are challenged to reflect upon their own participation in the reading and interpretation of this novel. They are faced with the reality of the once-occurrent, never-repeatable, and participative nature of their own reading acts. One of Bakhtin's elaborations on the architectonic experience or act could have been taken directly out of Grass's novel: "Nothing in Being, apart from myself, is an I for me. In all of Being I experience only myself -- my unique self -- as an I. All other Is (theoretical ones) are not I for me, whereas my own unique (non-theoretical) I participates in once-occurrent Being: I exist [ego sum] in it" (Toward a Philosophy of the Act 41). Oskar's explanation of how he was born a mentally fully developed adult with an almost clairvoyant consciousness (The Tin Drum 52) parallels that harmlessly egocentric observation by Bakhtin. Or, perhaps this is better described by the term egoconsciousness. Before anything else in the world, Oskar attains a sense of self (in stark defiance to Jean Piaget's conventions of child development, one may add here). And, based on that sense of self, every additional encounter is evaluated. However, here one already faces a small problem in the narration act, one that nevertheless serves as another indication of Grass' architectonic approach for his narrator Oskar. On the very first page of The Tin Drum, Oskar tells his readers of his current situation, his existence as a sanatorium patient, which also serves as the space-time reference of Oskar's narration acts. Here he tells us how he has grown to appreciate one of the male nurses, Bruno, whom he often tells of his past adventures as he revels in his memory acts. Thus, Bruno becomes another fellow audience member, next to the reader. The verb that Oskar uses initially to describe how he conveys his tales to Bruno is vorlügen, a word that combines the two aspects of narration and lying, not unlike the English concept of sailors spinning their yarn (9). Throughout the novel there are instances where the reliability of the narrator is brought into question, but it is nowhere as blatant as here. However, this term of vorlügen appears to be used in a playful manner, perhaps even as a sardonic commentary on Socrates's/Plato's distrust of poets. Since Oskar takes significant pains in telling every little detail of his adventures, it would be misreading the text to assume that his story is simply a lie. It is more aptly described as a conscious act of creation of a story in reference to the many onceoccurrent, never-repeatable, participative acts of the past, recalled by memory acts, which are in and of themselves necessarily once-occurrent, never-repeatable, and participative as well.

Oskar later even seems to contradict himself in regard to his intentions when he speaks of his "hoffentlich genaues Erinnerungsvermögen," his "hopefully precise ability to remember" (11; my translation: while it is standard practice in scholarship to use a standard translation of foreign language works, my analysis of Grass's text requires my own translation). Still, he distinguishes carefully 
Stephan Schaffrath,

"The Methodology of Architectonic Truth-Finding in Grass's The Tin Drum (Die Blechtrommel)" page 5 of 12

CLCWeb: Comparative Literature and Culture 9.4 (2007): <http://docs.lib.purdue.edu/clcweb/vol9/iss4/2>

between the event that occurred and the memory thereof. And, when he asks Bruno to please buy for him a ream of writing paper, he asks specifically for "innocent paper," suggesting that the act of story telling is to be done afresh, as a new act, although it may involve less than innocent participatory narration acts, the kinds that may violate the paper's innocence. Bruno even tells Oskar how, to Bruno's surprise, the saleswoman blushed as she was asked for "unschuldiges Papier," as if she sensed the less than innocent intent on part of the writer, the consumer or violator of innocence perhaps (11). Maybe this innocent white paper, which is about to be consumed/violated, serves also as a reference to Oskar's many suspected as well as documented lineages and the history of his hometown Danzig, both of which involve the not so distant clearing and tilling of virgin forests by Baltic, Slavic, and Germanic peoples and the even less palatable historical fact of peoples' mutual raping of members of one another, figuratively as well as literally, in the sense of consumption and violation. It is also in the beginning pages of The Tin Drum where we read Oskar's thoughts on the act of how a story ought to be set up. Here too, readers may witness further architectonic traits of the text. Oskar muses: "You can begin a story in the middle and then cause confusion by boldly striding forward and backward. You can present yourself as a modern, eliminate all times and distances, and lastly announce or let announce that you have finally and in the final hour solved the space-time-problem" (12). The narrator is very much aware of the space-time continuum, which coincidently also forms the basis for Bakhtin's architectonics. Oskar elaborates: "I have also endured being told that it will appear as good and modest when you affirm in the beginning [of a story]: there are no novelistic heroes left, since there are no more individualists, since individuality is gone lost, because people are lonely -- every person is equally lonely -- without any right to individual loneliness and because humanity forms a name- and heroless lonely mass" (12). He counters such suggestions of feigned philosophical and intellectual prowess with his own personal view on how the individual ought to be seen: "That may be so and perhaps accurate. For me, Oskar, and my nurse Bruno I would however like to make the following assessment: We are both heroes, completely distinct heroes, him behind the peephole, me in front of the peephole; and when he opens the door, we are both, in consideration of all friendship and loneliness, still not a name- and hero-less mass" (12).

It is the individual and the individual's unique experiences to other individuals that define one's identity. And this is where Grass's philosophy of narration in the words of Oscar parallels Bakhtin's ideas of how human beings relate to one another. Identity is not so much about what one accomplishes; it is more about self-perception and the interactions with others that define one's identity and the social status connected to it. Oskar's example of seeing and being seen through his room's peephole is a perfect example for this, and it is emphasized by the hyperbolic use of the word "hero." This goes hand-in-glove with Bakhtin's definition of recognition of other people within the concept of the architectonic: "That I, from my unique place in Being, simply see and know another, that I do not forget him, that for me, too, he exists - that is something only I can do for him at a the given moment of Being: that is the deed which makes his being more complete, the deed which is absolutely gainful and new, and which is possible only for me" (Toward a Philosophy of the Act 42). Within Bruno's and Oskar's microcosm of the sanatorium room, the other becomes clearly significant, elevated even to protagonist status. It is not important what the rest of the world deems important but what the immediate experience or "participatory act" shows as significant. Thus, Grass's philosophy of narration appears to be less than coincidental. It appears as an important and deliberate commentary that is built into the framing device of this story. It shows not only Grass's thoughts on the subject of what storytelling entails, but more importantly sets the tone for how readers are to understand Oskar's role as the narrator. The first sixty-some pages of the novel, where Oskar identifies himself overtly as a participative narrator and explains his own philosophy on what it means to be a narrator, is not the only place where readers may learn about The Tin Drum's narrative characteristics as they may relate to truth-finding methodology. Another significant aspect of truth-finding methodology relates to Oskar's many fantastic and less than credible claims. Among the more obvious are of course his asser- 
Stephan Schaffrath,

"The Methodology of Architectonic Truth-Finding in Grass's The Tin Drum (Die Blechtrommel)" page 6 of 12

CLCWeb: Comparative Literature and Culture 9.4 (2007): <http://docs.lib.purdue.edu/clcweb/vol9/iss4/2>

tion of having been born with a fully-matured consciousness, his decision to stop growing at age three, as well as his sudden growth-spurt on the refugee train, his ability to shatter glass through singing, and his story about the eerie Niobe figurehead that his friend Herbert felt magically compelled to impale himself on. And there are a number of characters that also appear to be the product of Oskar's imagination or at least the subjects of his embellishment, although most of them seem at least plausible in their general existence.

I focus here on four characters of the novel (it should be noted that at least two of the four did not appear in the original edition of the novel; see Reddick), Josef Koljaiczek, Bebra, Schugger Leo, and "die schwarze Köchin" (Ralph Manheim, the translator of the 1961 Vintage edition of The Tin Drum, calls her "the black witch," which is not an unfitting translation since readers get to know the schwarze Köchin as a symbol of impending doom rather than someone who is actually preparing meals. But, even "black witch" does not convey the image of a middle aged, heavy-set, sweaty woman holding a butcher's knife or at least a rolling pin. Literally, this character's name translates as "black female cook," a less than satisfactory English descriptor for the mental image that the term schwarze Köchin conjures up in the German psyche. In German, "schwarz" in relation to people is commonly used to refer to hair color and sometimes an ominous personal character. The latter would be the most fitting definition in this case). Oskar's grandfather Josef Koljaiczek serves as the first as well as clearest example of the narrator's tendency to embellish the stories of his narrative's characters. Throughout the book, Oskar more or less mentions his grandfather's successes randomly, as an industrialist in the United States, when in fact he was last seen (or heard of) fleeing from the Prussian police and diving underneath a large float of timber logs awaiting cutting in a sawmill. Oskar admits that he does not know the true fate of his grandfather, but that fact does not keep him from making clearly unfounded assertions of wishful thinking. Another character whose existence is even more questionable, although more plausible than that of Josef Koljaiczek, is Meister (Master) Bebra, the director of the traveling circus that Oskar joins for a short while during the war years. Meister Bebra is certainly not an unlikely character, although it is not clear whether Oskar made him up or not. There are two reasons for such skepticism: first, no one in Oskar's family ever gets to meet Meister Bebra in person, and second, Meister Bebra reappears after the war as the larger-than-life manager of a concert agency which hires Oskar to go on tour with his almost magic tin drum (731). The character Bebra represents simultaneously Oskar's mentor, employer, and confessor of his supposedly evil deeds, the deaths of several people who were close to Oskar. The next character who may be counted as a product of Oskar's imagination or at least embellishment is Schugger Leo ("Schugger Leo" is best translated as "Leo of the Schugger family" or "the Schugger's Leo," both of which are a bit cumbersome; hence I keep Schugger Leo). Similar to Meister Bebra, Schugger Leo appears usually when Oskar is not around any of the certifiable characters, his close family members and neighbors. In this sense, Meister Bebra and Schugger Leo qualify as candidates for imaginary friends, especially since both of them are tied to some of the fantastic and out-of-this world aspects of Oskar's story. Schugger Leo makes his first appearance in the novel when he shows Oskar where his mother's cousin/possible father Jan Bronski, was buried after his execution by the German militia during the first days of the war. Leo is described in ways that characterize him as a mysterious man, at least, or a creature from another, darker dimension, at most. The former (fallen?) priest seminar student (326), scares Oskar, carries with him, and uses as a musical instrument the empty cartridge of the bullet that murdered Jan Bronski (32731), "gave -- in his multi-folded, startling white shirt -- the appearance of a figure adventurously reminiscent of medieval dungeons" (329), "broke out again and again into laughter, which each time he ended by beating his wings, like a cawing raven" (329), leads Oskar to the telling Skat playing card Seven of Spades of Jan Bronski's (332), and finally disappears: "he moved around and ahead in ghostlike fashion, until sways of ground-clinging fog devoured him" (332). Leo's last name, Schugger, sounding similar to the commonly used Yiddish word meschugge -- denoting craziness or insanity -- is perhaps another hint that Grass grants his readers and Schugger Leo reappears later in the story. Fur- 
Stephan Schaffrath,

"The Methodology of Architectonic Truth-Finding in Grass's The Tin Drum (Die Blechtrommel)" page 7 of 12

CLCWeb: Comparative Literature and Culture 9.4 (2007): <http://docs.lib.purdue.edu/clcweb/vol9/iss4/2>

ther adding to the question of whether he ought to be considered a concrete character, a figure of Oskar's imagination, or a little bit of both is the fact that now he goes by a different name, Sabber Willem (William of the Sabber family, sounding similar to sabbeln, meaning "to slobber," as does a person who does not have full control over his body). Is this the same person that Oskar knew from Danzig? Or, is this a person whom he encounters in his post-war existence in the West who reminds him of Leo? Oskar rationalizes and deliberates his confusion: "After all I existed before in Danzig. And now I exist in Düsseldorf, and my name is still Oskar ... We drove past Sabber Willem. He greeted me with his white glove, and I felt just like home on the Südfriedhof [a cemetery]" (583-84). He believes that the person he meets in Düsseldorf is in fact Schugger Leo, either literally or archetypically. The young man known as Sabber Willem triggers a memory of an experience he has had with a person in his former life in Danzig, regardless of whether or not this person is the actual Schugger Leo.

More important than the true identity of Schugger Leo/Sabber Willem is the critical commentary that is built into Oskar's consciousness as a narrator. Readers are shown the distinction between the identity of a person and an experience (a once-occurrent, never-repeatable, participatory act) that one may have with that person, an experience which can contribute to one's formation of an opinion about or view of this other person's identity. The final character who is less than concrete -- and this one is probably the most ephemeral of them all -- is the schwarze Köchin. Most telling of all, however, is the fact that the schwarze Köchin is really not a character in flesh and blood as she is the central figure in a macabre nursery rhyme. In The Tin Drum this character does come alive, albeit in Oskar's imagination, as it seems. She is still real enough to affect Oskar in real ways, especially as she becomes one of the characters from whom Oskar is fleeing. So what is the significance of these four characters, especially in context to architectonic truth-finding methodology in regard to narration? These characters add to this novel's approximative truth-finding methodology in two ways. First, Oskar's narration includes some characters who are at least partly embellished and others who appear to be imaginary. Oskar's interaction with these characters that are at least somewhat admittedly fictitious leads readers to an architectonic -- and therefore approximative -- understanding (or consciousness) of the narration process. Oskar's narration presents readers with information that appears partly reliable and partly unreliable, helping readers' distinguish between Oskar's actual experience in the past and his telling of these experiences in the present, including all their embellishments. Both are distinct, participatory acts in and of themselves. Secondly, these more or less fantastic characters add to Oskar's persona as a larger-than-life and out-of-this-world narrator, his singularity, and therefore his once-occurrent and never-repeatable existence, and his consciousness thereof. Oskar's tendency to make himself the epic hero of his narration has less to do with an overdeveloped ego than with Oskar's belief that everyone intrinsically has a right to be the center of one's narrative, as shown in this earlier quoted excerpt from the beginning of the novel: "For me, Oskar, and my nurse Bruno I would however like to make the following assessment: We are both heroes, completely distinct heroes, him behind the peephole, me in front of the peephole; and when he opens the door, we are both, in consideration of all friendship and loneliness, still not a name- and hero-less mass" (12). Oskar considers Bruno, his male sanatorium nurse, no less a hero than himself. This is a clear indication that Oskar narrates himself into the grandeur of an epic character not because he thinks that he alone could fill such a position. This excerpt is proof that Oskar thinks of every person as a hero. It all depends on one's consciousness of the singularity of one's existence and the significance thereof: in other words, the consciousness of one's once-occurrent, never-repeatable, participatory, and therefore architectonic existence. A final point worth making would be Oskar's reference to himself in the third person: on the surface, this habit appears simply as a quirky idiosyncrasy of the narrator. However, whenever Oskar refers to himself as if he were talking about another person, he in fact is doing exactly that. From an architectonic point of view, Oskar's reference to his former self (and perhaps "the self persona" that he is inventing for his audience) is a commentary on the irretrievability of the past. The Oskar of the 
Stephan Schaffrath,

"The Methodology of Architectonic Truth-Finding in Grass's The Tin Drum (Die Blechtrommel)" page 8 of 12

CLCWeb: Comparative Literature and Culture 9.4 (2007): <http://docs.lib.purdue.edu/clcweb/vol9/iss4/2>

1920s, 30s, and 40s is frozen in time; he is a never-repeatable, once-occurrent, and participative phenomenon.

Storytelling, especially in context with the historical backdrop of the novel constitutes another way in which The Tin Drum shows signs of architectonic truth-finding methodology. Grass blends together two concepts that are usually neatly separated into two distinct and not-so-blendable items, the two concepts of fact/non-fiction (on the one hand) and fiction (on the other). These two concepts are represented by references to factual historical events and by Oskar's creative and very personal narrative style, respectively. This blending of fiction and non-fiction creates a world that comments on the interconnectedness of story-telling and history-telling, a world that is simultaneously novelistic and historical. As Kim puts it, "Grass' realistic representation of history accomplishes a historical complexity which cannot be achieved by academic history books" (80). Readers' understanding of historical events as they are depicted in The Tin Drum hinges clearly on the narrator's admitted subjectivity, which in turn depends directly on his architectonic perspective of the world that centers on the immediacy of the participatory act, which is once-occurrent and never-repeatable. In The Tin Drum, we are constantly reminded that history-telling (just as story-telling) relies on once-occurrent, neverrepeatable narration acts. The intent of the historian and the novelist may differ -- one intends to convey information about what did take place and the other intends to convey information about the human condition of very real people by means of mostly invented characters -- but they both are interested in helping readers relate to the general human condition. The Tin Drum relates history in an indirect, yet meaningful way, through the stories about individuals, narrated by the one and only narrator, the master of puppetry, Oskar. We learn about German history starting from 1899 into the 1950s almost exclusively through the context of the stories that involve Oskar himself and/or his acquaintances, friends, and relatives. Any reader who is not familiar with German history during this time would in fact get a less than complete history lesson (in the traditional sense, at least), since there are only more or less cursory mentions of various aspects of the late 2nd empire, the Weimar Republic, the 3rd empire, the Second World War, the holocaust, the allied occupation, and the early Federal Republic of Germany (Ervin Brody describes how the Holocaust is dealt with in The Tin Drum, not in all its horrific detail but in a personalized, yet meaningful way: "The Holocaust is not the main theme of the novel, yet it is significant because of its strategic sensitivity as a background. Thus, Grass' muted irony distances the catastrophe of history and traces their effects largely in terms of private lives," such as the Jewish toymaker Sigismund Markus or the Jewish holocaust survivor Fajngold who still gathers his invisible family around him, unable to cope with the fact that they were all murdered in a German concentration camp [97]). The Tin Drum was never intended as a replacement of history books. But it proves a useful supplement or complement to the "non-fiction" accounts of historians. Novels whose plots are deeply entangled in the web of history, such as The Tin Drum, remind the reader of the limitations of the academic discipline of history and the cultural and academic icon of the historian. In an interview with Manfred Durzak, Grass even publicly and overtly voiced his doubts about the degree to which historians' depictions of our collective past can be said to be based on fact (17). Historically entangled or engaged novels are free to experiment and explore the realm of immediately experienced or "participatory" history as it has been lived by those who have been there.

While The Tin Drum may serve as a supplement to more traditional and intentionally objective accounts of history, it nevertheless stands on its own two feet as a novelistic narrative that is imbedded in and interwoven with history. As a novel, its purpose is not to serve as one of several ways to provide a more complete picture of German history in the first half of the Twentieth Century, although it certainly may be viewed or applied this way. More importantly, as a novel, The Tin Drum tells its own story, the story of unique human beings (and one in particular) dealing with their very unique situations. Although these characters are fictional, they are necessarily grounded in the context of historical reality, and not just to allow for the readers' suspension of disbelief but as a reflection of immediate and participatory history, the history that a person actively experiences through once-occurrent, nev- 
Stephan Schaffrath

"The Methodology of Architectonic Truth-Finding in Grass's The Tin Drum (Die Blechtrommel)" page 9 of 12

CLCWeb: Comparative Literature and Culture 9.4 (2007): <http://docs.lib.purdue.edu/clcweb/vol9/iss4/2>

er-repeatable, participatory acts. Oskar's approach to history is all at once epic, personal, and -- despite of his penchant for creative storytelling -- historically grounded and relevant, in its own right (according to Neuhaus, these allusions to greater things serve the purpose of giving Oskar's narration more dignity (100). However, I see a more subtle, yet more significant reason for Oskar's habit of placing himself on the stage of world events: to pay respect to the once-occurrent and never repeatable nature of each participatory act. Oskar sees himself as a central character within the story/history of Germany during his time, yet he is not suffering from the kinds of delusions of grandeur that would keep him from staying in touch with the reality of his personal relationships. And, although his worldview is not that of a sober-minded historian, he observes the historical significance of the events of his days shrewdly, albeit with a good dose of sarcasm and even egocentrism. One of the most overt examples compares Oskar's sexual affair with an older woman to the stalling military campaign in Soviet Russia, as the German offensive is bogged down: "Vjazma and Brjansk [places in Russia]; then the muddy phase began. Oskar as well began to fiercely dig in the mud in the middle of October of '41. One may reproach me for comparing the muddy successes of the Heersegruppe Mitte [the central section of the German army in Russia] with my own successes in the difficult and also very muddy terrain of Mrs Linda Greff. As tanks and trucks got stuck in the mud near Moscow, I got stuck too; I certainly didn't give up -- I managed literally to beat foam from the Greffly mud -- but there weren't any noteworthy advances, neither on the road to Moscow nor in Mrs. Greff's bedroom" (399). Readers learn about the military history of the Second World War in a very indirect and personal, yet not erroneous manner. Oskar's comparison of his own personal experiences with sexuality with that of the huge military undertaking of the Russian campaign is obviously overblown and somewhat tongue-incheek. However, this comparison makes readers think about the significance of personal experiences, namely the once-occurrent, never-repeatable act. Although Oskar was invading merely the netherregions of an older consenting woman, who was neglected by her pedophile husband, to him this sexual experience was just as significant -- if not even more significant -- as the earthshaking (or mudsplashing?) news from the Eastern front.

All of Oskar's many personal anecdotes illustrate not only Oskar's story but also Germany's history. Oskar plays many roles and thus could be seen to represent not only one particular German but Germany as a whole, in particular as it relates to the eastern portions of Germany, territory that Germany lost after 1945 (I refer here to regions that were part of Germany before and during the two world wars and became part of Poland and the Soviet Union after the war; Danzig takes a special place here, as it was a sovereign city state between the two wars). As such, Oskar's narration act becomes an alternative history of the eastern portion of the late German Empire, one that takes into account the once-occurrent, never-repeatable, and participatory nature of lived history, as Oskar focuses his narration on experiences that he himself has been part of. There are at least nine aspects of Oskar's character that make him a representative of several aspects of Germany and especially Germany's lost territories: First, Oskar, as a person of stunted growth, is a default target of discrimination and worse, initially as he falls victim to other children's cruelty and then as an obvious candidate for Nazi "euthanasia," a fate which he nevertheless escapes, unlike many of those whom Hitler's regime labeled as either undesirable, unfit, or dangerous in the pursuit and advancement of purification of the Aryan race. Many of these people were German citizens or at least lived within the sphere of German political influence. Oskar thus represents the ostracized, marginalized, and persecuted German; Second, Oskar, as a little person of wunderkind intellect and imagination, may serve as a parody of Immanuel Kant, the famous German philosopher of small stature who was from Königsberg (Kaliningrad), another city near the Baltic Sea that Germany ceceded after the Second World War; Third, Oscar is ethnically not purely German, but at least half Kashubian, i.e., of Slavic descent, another aspect that makes him a representative of so many Germans of diverse ethnic background, though culturally very Germanic. This was the case for many people who lived on the former eastern fringes of Germany (see Gesche 149-71); Fourth, Oskar is a collaborator with the Nazis as he becomes employed by a 
Stephan Schaffrath,

"The Methodology of Architectonic Truth-Finding in Grass's The Tin Drum (Die Blechtrommel)" page 10 of 12

CLCWeb: Comparative Literature and Culture 9.4 (2007): <http://docs.lib.purdue.edu/clcweb/vol9/iss4/2>

circus to entertain the German troops in Normandy. Oskar even becomes quite friendly with one of the German soldiers, Lankes; Fifth, Oskar is an admitted murderer. He claims responsibility for the deaths of both his parents, although his guilt is certainly debatable. As such he is a bearer of guilt, perhaps representative of the collective guilt burden of post-Second World War Germany. Similar to Oskar, many Germans who never directly committed any acts against humanity still felt and feel guilt for the genocides committed in the name of Germany. Grass himself recently revealed that he became part of the infamous Waffen SS as he turned 17, making him no stranger of personal and collective guilt (on this, see, e.g., Reese; Riding)). After the war, Grass obviously regretted his involvement with the Waffen SS, and he became an outspoken critic of anything that even remotely smelled like nationalism; Sixth, after the war, Oskar grows from the stature of a three-year-old to a still below average height but deformed hunchback. In this sense, he may be said to represent Germany's postwar geographical and mental state (Arnds even compares Oskar's physical state to Germany's ugliness [61]). Indicative of this geographical and mental deformation of Germany at the end of World War II and towards the post war years is the fact that Oskar grows only as he is in the process of leaving Danzig for what would soon become known as West Germany. Oskar's deformation happens as he is burying his official father, Matzerath, and shortly before he is leaving the part of Germany that would no longer be Germany. The child's body can no longer maintain the deformed nature of its owner. Germany becomes physically cut up into several chunks. Mentally, Germans become fully aware of the horrors of the holocaust that were committed in their names and with their at least implicit collaboration. The less than innocent Oskar can no longer sustain the innocent façade of a three year old boy as he travels from the Danzig of his memories to the bombed out cities of his future as a citizen of the Federal Republic of Germany, a place that Grass often criticized as less of an independent country than somewhat of a political satellite to the United States; Seventh, Oskar is a false messiah, as he identifies with and even claims to be Jesus. In the final years of the war he joins a local gang of juveniles, the Stäuberbande, and becomes their leader. Oskar uses his leadership positions within the gang to break into a church where he puts himself in the arms of a Madonna statue, replacing a baby Jesus figurine. This is conceivably a cynical allusion to Adolf Hitler, who has his minions install him as the emperorlike leader of the new Germany and as the savior of the "Aryan race." Neither Oskar nor Adolf have a legitimate claim to the messianic thrones they respectively claim; Eighth, Oskar uses his art and skill for the purposes of both creation and destruction, two things Germany has been known for in recent history. His drum is the tool of creation, and his voice is the means of destruction. With his tin drum -a musical instrument reminiscent of the military prowess of Frederick the Great's Prussian army, although painted in the red and white colors of the Polish flag (see Brody 98) -- Oskar conjures up many a telling melody accompanying him through the throws and punches of life. With his high pitch he sings all kinds of objects made of glass into tiny shards; and Ninth, Oskar is a colonizer and invader. He claims to be the true father of Kurt, his half-brother. His sexual encounter with his stepmother Maria could be seen as an act of colonization, not unlike that of the Teutonic Knights who first brought and established Deutschtum (German culture and identity) onto the shores of the eastern Baltic Sea. Oskar's seed takes the place of the rightful owner, his father Matzerath.

However, most fittingly, Oskar represents Danzig, which is and is not a German city, just as Oskar is and is not German. Anna Koljaiczek, his Kashubian grandmother, puts this into perspective, as she proclaims in East Prussian German vernacular: "and when someone is a Kashubian, then that's not sufficient, neither for the Germans nor for the Polacks. They always want it just so" (547). Oskar, who is either half or fully Kashubian, is nevertheless considered German since both his official father and stepmother are German. Emotionally, however, Oskar is more Kashubian than German. His narration is replete with nostalgic references for his Kashubian grandparents, mother, and uncle/potential father. Although the Kashubes are ethnically and linguistically closely related to the Poles, they had lived under German/Prussian rule for centuries which caused many of them to become substantially Germanized. Oskar, just like Danzig, is a product of the very diverse and even tumultuous ethnic influ- 
Stephan Schaffrath,

"The Methodology of Architectonic Truth-Finding in Grass's The Tin Drum (Die Blechtrommel)" page 11 of 12

CLCWeb: Comparative Literature and Culture 9.4 (2007): <http://docs.lib.purdue.edu/clcweb/vol9/iss4/2>

ences and often violent history of the southeastern coast of the Baltic Sea. When the Russians come through Danzig and do the many horrible things that many a victor does when he conquers a place, Oskar puts this event into perspective of the many centuries of conquerors, occupiers, claimants, destroyers, and re-builders of his hometown (520-23). Now that Danzig becomes Polish, there is no longer room for those Germans and half-Germans who survived the war. On this, I would like to mention Janina Gesche's Aus zweierlei Perspektiven. Zur Rezeption der Danziger Trilogie von Günter Grass in Polen und Schewden in den Jahren 1958-1990 and Carl Tighe's article "The Tin Drum in Poland" who go into great depth and provide valuable insight into the relationship between post-war Poles toward their newly attained territories and ethnic and cultural Germans who either used to live or to some degree still live in these areas. For instance, they show in great detail how Polish translations of The Tin Drum purposively make Danzig look like a Polish city, even during times when most inhabitants of Danzig would have identified themselves as German, at least culturally, ethnically, and linguistically. The Kashubes (or Kaszubians, as Tighe spells them) are also shown as a Polish ethnic goup, despite their own cultural heritage and identity. Despite Grass's sympathy for the Polish and his admittance that Danzig/Gdańsk ought to be considered a Polish city after the end of the war, the ruling Communist Party of Poland was still not satisfied with Grass's depiction of German culture as the inherently main culture of formerly German or independent and presently Polish places like Danzig. And in his article, "The Polish-German Conflict in Guenther Grass' Danzig: Pan Kishot in The Tin Drum," Ervin Brody presents a Polish-centered perspective, one that is equally insightful and useful [may he be forgiven for misspelling Grass' first name]. Herman Beyersdorf, too, is worth mentioning here as a contributor to the topic of displacement of ethnic Germans in literature and reality).

Oskar, his stepmother Maria, and Oskar's alleged son and official half-brother all leave for the West to live with Maria's relatives. This is where the displaced German-Kashubian young man sets out on a new journey, one that ends with him being committed to a sanatorium. And Oskar's room in the sanatorium serves as place and time reference of the narrator, the Oskar who recalls the events that the earlier Oskar experienced, through once-occurrent, never-repeatable, participatory acts. After Oskar explains his current situation as a writer and patient in a sanatorium, he segues directly to the story of his maternal grandparents. The first chapter, "Der weite Rock" ("The Wide Skirt"), sets the tone for this personally connected and relevant historical narration. The name of this chapter refers to the four skirts that Oskar's maternal grandmother usually wore, one on top of another, rotating the innermost to the outermost position on a daily basis. This onion-layer-cliché reference is of course laden with symbolism (Beyersdorf, for instance, points out the four-fold skirt's representation of the "thematic concept of homeland, understood not just as the chronologically passed homeland of [Oskar's] childhood, but also the lost homeland of the east in a special sense" [52]). Especially in view of how Oskar explains his own ethnic origin, each layer of the skirt perhaps represents an ethnicity and/or the identity that goes along with it, depending on the historical circumstances. To illustrate, Oskar tells us a bit about the history of Danzig, one of the few traditionally historical passages of this novel: "First there were the Rugiers, then came the Goths and Gepides [all three Germanic tribes], followed by the Kashubes [a Western Slavic tribe], from whom Oskar descends directly. Soon after, the Poles sent Adalbert of Prague [a missionary]. He came with the cross and was slain with the axe by the Kashubes or the Prussian [the original Baltic tribe, not to be confused with the German Prussians, who came later]. This happened in a fishing village, and the village was called Gyddanyzc. Gyddanyzc was changed to Danczik; Danczik became Dantzig, which later was spelled Danzig [the German spelling]. And, today Danzig is called Gdańsk [its Polish name]" (520)

In conclusion, The Tin Drum presents us with a collage of traditional historical accounting (as the one above) and personal narrative. However, it appears that these two elements are not set to contradict or even contrast one another. Rather, Oskar's narration combines and complements the history of Danzig with the history of the Danziger, in this case Oskar himself, who represents and even signifies this city to readers. Grass shows us that the genre of the novel can indeed convey history in a 
Stephan Schaffrath,

"The Methodology of Architectonic Truth-Finding in Grass's The Tin Drum (Die Blechtrommel)" page 12 of 12

CLCWeb: Comparative Literature and Culture 9.4 (2007): <http://docs.lib.purdue.edu/clcweb/vol9/iss4/2>

fictitious format (an otherwise standard recognition in the humanities today), yet be a useful and insightful medium to those who wish to learn about history in the sense of a factual genre. Grass achieves this by educating his readers about the fine line between fact and fiction as he interweaves a most intricate epistemological commentary into the narrative of his narrator. Thus he creates an architectonic history account of the city of Danzig/Gdańsk in the first half of the twentieth century, a history that takes into account the distinction between the act of narration and the act of immediate experience, both of which are once-occurrent, never-repeatable, and participatory in their own rights. Thus, when novelists apply architectonic truth-finding methodology, they help readers not only to explore the traditional historical perspective of a place; they also challenge readers to discover the complex psychology as it pertains to conveyers of history.

\section{Works Cited}

Arnds, Peter O. Representation, Subversion, and Eugenics in Günter Grass's The Tin Drum. Rochester: Camden House, 2004.

Bakhtin, M.M. The Dialogic Imagination. Trans. Caryl Emerson and Michael Holquist. Ed. Michael Holquist. Austin: U of Texas $P, 1981$.

Bakhtin, M.M. Toward a Philosophy of the Act. Trans. Vadim Liapunov. Ed. Vadim Liapunov and Michael Holquist. Austin: U of Texas P, 1995.

Beyersdorf, Herman. "'...den Osten verloren.' Das Thema der Vertreibung in Romanen von Grass, Lenz und Surminski." Weimarer Beiträge 38.1 (1992): 46-67.

Brody, Ervin C. "The Polish-German Conflict in Guenther Grass' Danzig: Pan Kishot in The Tin Drum." The Polish Review 41.1 (1996): 79-107.

Durzak, Manfred. "Geschichte ist absurd. Eine Antwort auf Hegel. Ein Gespräch mit Günter Grass." Zu Günter Grass. Geschichten auf dem poetischen Prüfstand. Ed. Manfed Durzak. Stuttgart: Klett, 1985. 9-19.

Jung, C.G. Die Archetypen und das kollektive Unbewußte. Solothurn: Walter, 1995.

Gesche, Janina. Aus zweierlei Perspektiven. Zur Rezeption der Danziger Trilogie von Günter Grass in Polen und Schweden in den Jahren 1958-1990. Stockholm: Almquist \& Wiksell, 2003.

Grass, Günter. Die Blechtrommel. München: Deutscher Taschenbuch Verlag, 1997.

Grass, Günter. The Tin Drum. Trans. Ralph Manheim. New York: Vintage, 1961.

Kim, Eung-Jun. Literatur als Historie. Zeitgeschichte in Thomas Manns Doktor Faustus und Günter Grass' Die Blechtrommel. Würzburg: Königshausen \& Neumann, 2004.

Lehmann, Jürgen. "Fragment als Form der Überschreitung: Günter Grass' Die Blechtrommel und Michail Bachtins Theorie des Romans." Konflikt-Grenze-Dialog. Kulturkontrastive und interdisziplinäre Textzugänge. Ed. Jürgen Lehman, Tilman Lang, Fred Lonker, and Thorsten Unger. Frankfurt: Peter Lang, 1997. 73-84.

Neuhaus, Volker. Günter Grass, Die Blechtrommel. Interpretation von Volker Neuhaus. München: Oldenbourg, 1988.

Plato. The Republic and Other Works. Trans. B. Jowett. New York: Doubleday, 1989.

Reddick, John. "Vergangenheit und Gegenwart in Günter Grass' Die Blechtrommel." Die Mühen der Ebenen. Kontinuität und Wandel in der deutschen Literatur und Gesellschaft 1945-1949. Ed. Bernd Hüppauf. Heidelberg: Carl Winter, 1981. 373-77.

Reese, Dagmar. "Günter Grass and the Secret." Dissent 54.1 (2007): 36-37.

Riding, Alan. "Nobelist is Bedeviled by SS Past." The New York Times (17 August 2006): E1-8.

Rohlfs, Jochen W. "Chaos or Order? Günter Grass's Kopfgeburten." The Modern Language Review 77 (1982): 88693.

Schaffrath, Stephan. Chaotics, Architectonics, and Truth-Finding Methodology in the Post-World War II British Novel: Approaching Approximations. Ph.D. Dissertation. Philadelphia: Department of English, Indiana U of Pennsylvania, 2004.

Schulte, Günter. Kant. Philosophie Jetzt! München: Deutscher Taschenbuch Verlag, 1998.

Tighe, Carl. "The Tin Drum in Poland." Journal of European Studies 19.1 (1989): 3-20.

Author's profile: Stephan Schaffrath teaches English and German literature at Slippery Rock University and at Indiana University of Pennsylvania. In his research, Schaffrath focuses on the psychological and philosophical aspects of literature, in particular how novels engage the reader and how literature explores concepts of truth. His recent publications include "The Many Facets of Chaos-versus-Order Dichotomy in Graham Greene's Waterland" in Interdisciplinary Literary Studies (2003) and "Order-versus-Chaos Dichotomy in Bram Stoker's Dracula" in Extrapolation (2002). E-mail: <stephan.schaffrath@sru.edu> 